Hubert Haider*

\title{
A null theory of scrambling
}

https://doi.org/10.1515/zfs-2020-2019

\begin{abstract}
Grammars are decomposable. On the one hand, an adequate characterization of a given utterance factorizes the contributions of each subsystem of grammar and on the other hand, it thereby reduces the apparent overall complexity to the interaction of less complex subsystems. Scrambling is an apt showcase. Its complicated properties are not inherent properties of a syntactic construction but the result of the interaction of phrase structuring with other subsystems of grammar, and in particular with the information-structuring (IS) subsystem of pragmatics. Scrambling is "utilized" rather than "triggered". In general, when syntax admits structural variation, this potential is captured and utilized by other subsystems of grammar. Germanic and Slavic languages are handy testimonies for rejecting syntactic trigger scenarios not only for scrambling but also for other constructions with displaced items. Cross-linguistically, scrambling is not a matter of syntactical determinism. For an adequate syntactical account of scrambling it is sufficient to understand and explain the structural conditions that make a language a scrambling language. The pragmatic functions that utilize scrambling structures are not a concern of syntax. They are syntactically not causal and epiphenomenal to syntax.
\end{abstract}

Keywords: scrambling, information structure, optional movement, triggers, Germanic, Slavic

\section{Introduction}

Scrambling is a showcase of the particular interplay between the availability of various degrees of structural freedom on the one hand and the independent utilization in diverse contexts on the other hand. Since these contexts are diverse, it is not surprising that the long-lasting quest for a particular syntactic trigger of scrambling has not proven successful. Here is a non-exhaustive sample of typical

*Corresponding author: Hubert Haider, Fachbereich Linguistik / Centre for Cognitive Neuroscience, Universität Salzburg, Unipark Nonntal, 5020 Salzburg, Austria, e-mail: hubert.haider@sbg.ac.at 
scrambling contexts in German. ${ }^{1}$

(1) a. Man hat $\left[\text { jedes }^{\mathrm{i}} \text { Auto }\right]_{\mathrm{j}}$ sofort seinem ${ }^{\mathrm{i}}$ neuen Besitzer $-\mathrm{j}_{\mathrm{j}}$ übergeben. one has each car immediately (to) its new owner consigned

b. Man hat die Gäste $e_{j}^{\mathrm{i}} \quad$ einander ${ }^{\mathrm{i}}{ }_{\mathrm{j}} \quad$ vorgestellt. $^{\mathrm{j}}$

Q-Binding one has the guests.ACC (to) each-other.DAT introduced

c. $\quad$ Er hat $[\text { mindestens eine Frage }]_{\mathrm{j}} \quad$ jedem Prüfling $-_{\mathrm{j}}$ gestellt. he has at-least one question every candidate asked

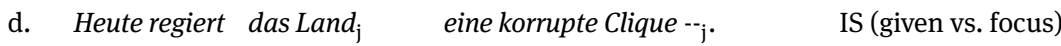
today governs the country.ACC a corrupt clique.Nom

e. $\quad D a$ hat die Bibel $l_{\mathrm{j}} \quad$ vielleicht jemand $--_{\mathrm{j}} \quad$ missverstanden. IS ("altruistic") there has the bible.Acc perhaps somebody.Nom misunderstood

f. dass den Mann derSchlag getroffen/der Teufel geritten/der that the man.ACc the stroke.Nom hit $^{2}$ the devil.nom ridden the

Hafer gestochen / ... hat.

oats.Nom pricked has

In (1-a), (1-b), scrambling makes available c-command relations between binder and bindee. In (1-c), the scrambled position of one of the quantified expressions disambiguates the scopal relation. The choice of the scrambled order conveys the information that the base order is dispreferred. So, the scrambling pattern is a way of disambiguating scope. In a language like English, which does not provide a simple ${ }^{3}$ order alternation, the utterance corresponding to (1-c) is ambiguously interpreted in its base order instead. ${ }^{4}$

(1-d) provides a serialization with the subject in the clause final area, which is the preferred area of focus-placement and therefore also for placing the questionanswer focus. The items that count as given precede it. The scrambling pattern

1 Abbreviations used in glossing examples: ACC - accusative; COMP - complementizer; DAT dative; DEF - definite; EXPL - expletive; GEN - genitive; IMPF - imperfective; INF - infinitive; $\mathrm{N}$ noun/nominalization; NOM - nominative; OBJ - object; PPT - past participle; PRT - particle; REFL - reflexive (pronoun); SUBJ - subject.

2 (i) Diesen Mann Acc $_{\text {hat der Schlag }}$ Nom getroffen. 'This man has suffered a (brain- or heart) stroke.'

(ii) Diesen Mann $_{\text {Acc }}$ hat der Teufel ${ }_{\text {Nom }}$ geritten. 'This man has taken leave of his senses.'

(iii) Diesen Mann sticht der Hafer $_{\text {Nom. }}$ 'This man behaves boisterously.'

3 English speakers would have to resort to other constructions, as for instance, the dative shift variant: [...] are prepared to hand over every square centimetre of land back to its traditional owners.

4 (i) ... asked every candidate at least one question.

Richard Montague's example of scopal ambiguity is well remembered: Every man loves a woman. English cannot disambiguate by simple word order change because its syntax does not provide the means. 
is perfect in the answer to a question that asks for the subject. It matches the ISpreferred partitioning of an utterance in given vs. new or background vs. focus areas with the subject as focus or new information.

When (1-e) is used, with the consequence that the verb receives nuclear stress, scrambling appears to apply “altruistically” (Fanselow 2003: 210). The reading for the scrambled version (1-e) is identical with the reading for the version without scrambling, provided the stress accent is placed on the verb and not on the object in its base position, which would be the default accent. In a written version of (1-e), this is guaranteed by resorting to the scrambling pattern. In the scrambled version, the base-position of the object is empty and trivially unstressed. Hence the verbal head as the only item in the deepest position receives nuclear stress. Syntacticians typically study written material rather than sound files. Therefore, such circumstances matter.

(1-f), eventually, illustrates a phenomenon that is absent in strict SVO languages (Haider 1993: 173, Haider 2013: 54). In such languages, idiom formation cannot join the verb and the subject while sparing the object as the referentially free constituent. The reason is that in SVO languages, there is an obligatory subject position outside of, and preceding, the verb phrase while the object is VP internal. So, an idiomatic sub-constituent that contains the subject and the verb necessarily contains the object. ${ }^{5}$ If in an SVO language, the subject and the verb are parts of an idiom, then the whole VP is part of the idiom and the object cannot be spared. In OV languages, scrambling is a way of forming a sub-constituent that contains only the subject and the adjacent verb. The object precedes and is not part of this sub-constituent. In the idiomatic usage, it is a free slot while the sub-constituent is treated as the idiomatic part.

What this brief exposition illustrates is the multi-purpose utility of scrambling patterns in a modular perspective on grammar. Scrambling is not syntactically triggered by any one of these grammatical requirements or preferences. The syntactically available patterns are utilized by other modules of grammar. Trivially, a language whose syntax does not provide such options cannot utilize them. Nevertheless, languages are able to cope with pragmatic demands also in the absence of scrambling. The potential utility has not forced grammars of such languages to change. In sum, scrambling is not a construction that is available in one language but not in the other. It is a syntactic system potential. It is - as will be explicated in the following section - a property of certain phrase structures and it is - if available - subsequently exploited by other components of grammar.

5 The items an idiom consists of in its "dictionary form" are continuous and idiomatized bottomup. O’Grady (1998: 293) credits this generalization to Kiparsky. 


\section{When inappropriate modelling leads to a dead end}

Scrambling is a challenge for a "mechanistic" view that assumes that items only move if they have to. Movement supposedly requires a trigger, otherwise an item would not move. In mainstream Generative Grammar (Minimalist Program), it is popular to directly syntactify desired properties in terms of features that trigger the necessary moves; see Breitbarth and Riemsdijk (2013: 8). In the absence of a restrictive feature theory, one is free to introduce a feature and declare it a trigger. For example, in cases such as (1-a), (1-c), a scope feature is deemed to make a scope-bearing item move to a c-commanding position where its feature gets checked (Hinterhölzl 2004, 2013: 183). For cases like (1-d), (1-e), an "anti-focus" feature has been suggested as the suspected trigger of scrambling by Molnárfi (2004). However, translating an empirical problem into a technical description is just a translation of a problem, not its solution. It is merely a restatement of facts in a technical notation. Apart from that, focus-avoidance would be an empirically inadequate trigger. It is known at least since Lenerz (1997: 63) that a questionanswer focus followed by non-focused items is a fully acceptable configuration in German. 6

When grammarians syntactify such properties (viz. information structure properties, semantic effects, etc.) as alleged triggers of syntactic structuring, they are apparently not aware of their essentially functionalist attitude. It is not the function of scrambling to satisfy information structure preferences or the needs of any other subcomponents, otherwise any language would employ it. Information structure preferences only utilize an independently available grammatical potential. The syntactical potential is the availability of alternative positions ${ }^{7}$

\footnotetext{
$6 \quad$ Q: Wem hast Du das Geld gegeben? whom have you the money given

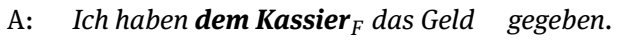
I have the teller the money given
}

7 The alternative positions are not pre-specified either, unlike what "Cartographic syntax" suggests. Syntactic cartography is but a restatement of usage-based properties, in a technical and partially circular way (s. Struckmeier 2016: 382, 2017: 9 and the literature cited there). A cartographic representation is just the structural notation of the pragmatic tuning of a clause. The properties it ascribes to structure are mere superposition effects of modules that meet and interact. The cross-linguistic complexity is the complexity of various interacting principles, but not the superposition of the aggregate of any functionally equivalent structures encountered in any odd language. 
within phrase structure. Besides IS, other subcomponents of grammar utilize the ensuing variability of linear ordering, too.

Generative Grammar continues modelling the relation between subcomponents in terms of stepwise derivations and seems to ignore the advancements in cognitive science over the last three decades in developing cognitively more adequate models of computing, namely parallel distributed processing, see Rogers and McClelland (2014) for a review. In such models, the contributions of different subcomponents become effective in simultaneous superposition rather than in a step-wise derivational sequence. In other words, a given utterance simultaneously meets the requirements of more than one subsystem. Information is not passed on from module to module, but shared by all modules instantaneously. Figure 1 is an example of superimposed structures. The focus-background partitioning of IS and the syntactic structuring are superimposed.

Let us assume that sentence (a.) in Figure 1 is part of an answer to a question such as "Who do they think will deliver the piano to their uncle?". In this case, the question-answer focus will be the subject of (a.). The remainder of the utterance is given information, that is, background information, and is preferred to precede. The serialization of the scrambled variant (a.) provides an accurate match between (b.) and (a.), as indicated in (c.). Hence (a.) is a preferred variant in this particular context by IS.

a. dass ihrem Onkel das Klavier eine hiesige Firma zustellen wird that her uncle Dat $_{\text {the }}$ piano Acc $_{\text {a local company }}$ Nom deliver shall

b.

$$
\rightarrow \text { background / given } \quad \text { focus / new }
$$

Figure 1: IS-partitioning superimposed on a syntactic structure.

The variant (a.) is the variant in which the IS-preferred partitioning for the utterance in (b.) can be neatly superimposed on the structural representation of (a.), with the result (c.), that is, the appropriate IS-mapping on a well-formed syntactic structure. This is a matter of simple pattern matching. If a language such as German admits serialization variations, this potential is exploited by IS. English does not provide such a potential.

In a cross-linguistic perspective, some types of phrase-structures are more "flexible" than others, as will be made precise below. Flexibility means that in some languages, there is variation among structure templates. This variation space can be partitioned by interacting modules when a module attaches some of its properties to some structures but not to others. Someone who thinks primarily in categories of syntactic derivations is misled into assuming syntactic principles 
to be semantically or pragmatically geared in order to guarantee a certain outcome. This neglects the fact that the systems involved are in superposition rather than connected in series of derivations. The triggering view is simple but misleading. This is not the way science models complex systems. Science decomposes systems; see Simon (1962), on "nearly decomposable" systems.

Interacting subsystems of grammar that are relevant for scrambling comprise phrase structuring on the one hand and pragmatics (information structuring), semantics (binding), prosody (focus), and others. Whenever there is more than one option for arriving at a well-formed structure, a deterministic account in terms of triggering is challenged since it has to identify a trigger, which does not exist, if the source of variation is a system potential that is available in one type of grammar but absent in another type, as in the case of scrambling.

Syntactic "movement" phenomena typically allow for choices in general. As for A'-movement, it is a well-known fact of German - which is representative of V2-languages in this respect - that in the main clause version (2-a) of an example such as (2-b), the clause-initial position can be filled by any one of the five underlined expressions. An additional option is waiving any fronting. Instead, the obligatory structural spec-position can be "plugged" with a syntactic dummy, namely the expletive item es 'it/there'.

a. ... werden in Zukunft vielleicht doch noch weitere Saurierreste are in future perhaps yet still further saurian-remnants auf $\frac{\text { Mallorca gefunden. }}{\text { Mallorca }}$

b. dass in Zukunft vielleicht doch noch weitere Saurierreste that in future perhaps yet still further saurian-remnants auf Mallorca gefunden werden at Mallorca found are

The actual choice of the clause initial item may be guided by preferences of information structuring, but this is a pragmatic and not a syntactic issue. Pragmatic preferences utilize syntactic options but cannot compel syntax to provide them. The particular choice of the constituent for lexicalizing the clause-initial position of Germanic V2-declaratives is not dictated by the grammar (= triggered). This insight ${ }^{8}$ has been grasped and published already in the $19^{\text {th }}$ century, by Erdmann (1886).

8 "Enthält ein Satz mehrere Bestandteile, so steht vor dem Verbum immer nur einer. Die Auswahl dieses einen aber ist im Deutschen völlig dem Belieben des Redenden überlassen.” (Erdmann 1886: 183) 
At least at this point, readers should feel tempted to object. In wh-interrogatives, a wh-phrase must be fronted in order to derive an interrogative clause in German, for instance. This is true (but the wording is accurate only if one believes in "movement") and it is nevertheless compatible with a non-deterministic choice-scenario. The grammatical principle that characterizes an interrogative clause with reference to the clause-initial spec-position of the main clause does not "select" or "attract" a wh-item. It merely defines the property of a wh-clause. Anyone uttering a wh-clause will have to activate the appropriate pattern with a wh-item in the top spec position. In case there is only a single option, the choice appears to be forced. Let us have a look at some details (3).
a. Gestern hat wen was schockiert. yesterday has whom what shocked 'Yesterday, something has shocked someone.'
b. Wen hat gestern was schockiert? whom has yesterday what shocked (ambiguous w. r. t. was: interrogative or indefinite)
c. Was hat gestern wen schockiert? what has yesterday whom shocked (ambiguous w. r. t. wen: interrogative or indefinite)

In (3-a), the unstressed ${ }^{9}$ wh-pronouns are interpreted as indefinite pronouns. The interrogative interpretation is in general restricted to wh-pronouns in specpositions and to wh-pronouns in-situ provided they are bound by a wh-pronoun in a spec-position. In fact, for a bare ${ }^{10}$ wh-pronoun in a spec-position, an indefinite construal is dispreferred. In other words, (3-b) and (3-c) are not interpreted as declarative clauses. ${ }^{11}$ So, there seems to be no choice. Is this a trigger situation?

(If a sentence contains several constituents, then only a single one occurs in front of the verb. The choice of the particular item is entirely up to the speaker. [Translation H. H.]).

9 If stressed, the utterance is an echo question, but not a regular wh-question.

10 If the wh-item is embedded in a fronted phrase, it may keep its indefinite interpretation, as Meinunger (2019: 178) reminds.

11 Even a discourse particle such as doch, which cancels an interrogative interpretation in V1-clauses (i), would not turn (3-b), (3-c) into fully acceptable declarative clauses with a clauseinitial indefinite pronoun:

(i) Hat doch schon Erdmann betont, dass Fragepronomina im Vorfeld nicht als has DocH already E. stressed that question-pronouns in-the prefield not as Indefinitpronomina fungieren. indefinite-pronouns act 
It is, if syntax is construed as a generative algorithm subserving semantics and pragmatics. It is not a trigger if syntax is understood as an autonomous structure projection system.

What syntax contributes is this: It characterizes the structural position and relation of the wh-pronoun and it types the clause. The essential difference between an interrogative V2-clause and a declarative V2-clauses concerns the item in the spec position. Interrogative clauses have an interrogative phrase in their spec-position. Hence (3-a) is a declarative clause, and (3-b), (3-c) are interrogative clauses. The impression of syntactic triggering arises only in a derivational model. This impression, however, is a theory-internal matter. (3-a) is not an ungrammatical would-be interrogative, and (3-b), (3-c) are not deviant would-be declarative clauses. These utterances each are syntactically well formed, but they differ in clausal typing.

In SVO languages, the situation is slightly complicated by the fact that the obligatory subject position in the $[\mathrm{S}[\mathrm{VO}]]^{12}$ clause structure is a spec-position. Whitems in spec-positions qualify as operators and resist being bound. So, a subject wh-pronoun in such a position does not tolerate being bound. Consequently, (3-b) is ungrammatical in English. For a detailed exposition of the grammatical intricacies of wh-subjects in situ in SVO, please consult Haider (2010: Ch. 3). Such a problem does not arise in SOV languages. The arguments of the verbal head - objects as well as the subject - remain in their base positions in the verb phrase. But even English provides choices for multiple wh-constructions, once one abstracts away from the special conditions that apply to the subject position of SVO languages:
a. When did he publish what? - What did he publish when?
b. When did he show up where? - Where did he show up when?

What English shows is this. The choice between alternatives may be narrowed down by grammatical restrictions on the elements involved. The limiting case is a context in which there is just a single option left. This context may be mistaken for a triggering situation: "This item has to move in order to ...". A simple and straightforward account is this: Such items are ungrammatical in-situ. Here is such a context:

12 This notation is used in order to emphasize that the relevant property for identifying a language as "SVO" is the particular clause structure and not merely the preferred order of subjectverb-object in a minimal clause consisting only of the verb, the subject and the direct object. Such orders are structurally ambiguous and therefore a misleading criterion. Typologists in the Greenbergian tradition stick to the order property and misclassify Slavic and Germanic SOV languages as SVO. The resulting set of languages is typologically inconsistent. 
a. It is unclear, why he contacted whom.

b. It is unclear whom he therefore/ ${ }^{\star}$ why contacted.

c. It is unclear whom he contacted therefore/ ${ }^{\star}$ why.

In English, and in SVO languages like English, but not in SOV languages, why and how are ungrammatical in any available in-situ position (5-b), (5-c); for an explanation see Haider (2010: 117). So, the only option is fronting. ${ }^{13}$ In OV languages, however, there is no such restriction and hence there is a choice:
a. Es ist unklar, weshalb er wen kontaktiert hat. it is unclear why he whom contacted has
b. Es ist unklar, wen er weshalb kontaktiert hat. ${ }^{14}$ it is unclear, whom he why contacted has
c. Es ist unklar, wen wer kontaktiert hat. ${ }^{15}$ it is unclear whom who contacted has

Since Generative Grammar has been developed mainly on the basis of grammatical properties of VO languages, namely English and languages like English (Romance, North Germanic), it is biased towards SVO languages. Consequently, typespecific [S[VO]]-properties have been elevated to the rank of universal constraints. One of these type-dependent properties is the specific behaviour of wh-subjects and of why and how as wh-forms for semantically higher order adverbials in SVO languages. In SOV languages, these properties are absent, as the examples (3) and (6) illustrate.

As for A-movement configurations, a particularly instructive case of a free choice situation is the Norwegian passive (Taraldsen 1979: 49; Lødrup 1991: 127).

13 For any pairing of how and why with a wh-subject in a simple English clause, there exists no well-formed configuration at all, since both compete for the clause-initial position and are ungrammatical in-situ.

(i) *Who objected why? - *Why did who object?

The ersatz is a coordination of two interrogative clauses (plus sluicing):

(ii) Who objected, and why?

14 (i) protokollieren, wen sie weshalb kontrolliert haben

(to) record whom they why checked have

(https://tageswoche.ch/stadtleben/grenzwaechter-schikanieren-obdachlose-baslerbahnhof/)

15 (i) $d a$ bis heute unklar ist, wen wer meinte since until today unclear is whom who meant (https://kurier.at/kultur/beethoven-2020-er-war-auch-superstar-und-revolutionaer/ 400715175) 
This language ${ }^{16}$ demonstrates how the full grammatical potential may be tapped when it comes to filling the obligatory structural subject position of an [S[VO]] clause structure. A potential filler for the subject position is, as expected, the direct object turned into a derived subject (7-a). In (7-b), the so-called pseudopassive, the complement of the prepositional object is fronted to the subject position despite the presence of a direct object. Eventually, in (7-c), the subject position is filled with a dummy subject although there would be candidates available for filling the syntactic subject position. (7-d) is the only unacceptable option since the subject position would remain empty. These patterns are identical for main clauses as well as embedded ones.
a. (at) frimerker ble klistret på brevet. that stamps were pasted on letter.DEF
b. (at) brevet ble klistret noen frimerker på. that letter.DEF was pasted some stamps on
c. (at) det ble klistret frimerker på brevet. that EXPL was pasted stamps on letter.DEF
d. *(at) ble klistret frimerker på brevet.

[Norwegian]

Obviously, there is no deterministic grammatical trigger at work in (7). Either an available item is fronted to the subject position or a dummy is used to lexicalize it instead. The alternatively available options of fronting either the direct object or the PP-internal noun phrase demonstrates that deterministic scenarios of fronting are inadequate. Even English displays the same phenomenon to a much larger extent than it is generally acknowledged. ${ }^{17}$ Bolinger (1975: 65) adduces examples such as (8), in which a PP-contained noun phrase is fronted across a direct object in a passive construction.

a. That city $y_{\mathrm{i}}$ has been fought many a battle over $-_{\mathrm{i}}$.

b. He $e_{\mathrm{i}}$ has been burned, stuck pins in -- , beheaded - all in effigy, of course.

c. $\left(\mathrm{PRO}_{\mathrm{i}}\right)$ to be whispered such dirty innuendos about $-_{\mathrm{i}}$ was enough to break any girl's heart.

d. (This tool has never been used for its main purpose) It $_{\mathrm{i}}$ 's never been done anything with $-_{\mathrm{i}}$ at all. ${ }^{18}$

16 In Danish and Swedish, prepositional passive is used infrequently (Engdahl and Laanemets 2015: 326). A pattern fully parallel to (7) is not attested in Danish or Swedish.

17 In English, idioms such as take advantage of or keep tabs at are usually cited as examples for the same kind of alternation: She was taken unfair advantage of. - Unfair advantage was taken of her. 
It is evident that the familiar narrative of Generative Grammar (cf. Truswell 2009) and LFG w. r.t. pseudo-passives fails in Norwegian (7) as well as in English (8). In an intransitive pseudo-passive construction, the verb is said to incorporate the preposition and to thereby turn the complement of the preposition into a (derived) object of $\mathrm{V}+\mathrm{P}$. This would evidently not work in the transitive contexts of (8). Incorporation of the preposition could neither apply in (8) nor in (7-b), but nevertheless there is a choice between fronting the direct object or stranding the preposition in the English examples and there is a free choice in Norwegian generally. The trigger scenario suggested in the standard analysis of NP-movement in passive in terms of case "absorption” and obligatorily A-moved direct objects in Generative Grammar is empirically contradicted by Norwegian and other languages.

In sum, this section is a reminder of a well-known maxim, namely the maxim of the autonomy of syntax; see Adger (2018) for a review. Syntactic rules and principles of a language do not anticipate and encode discourse functions. Discourse functions utilize the available grammatical potential of syntactic structuring. In particular, scrambling is not driven by syntactified features. Scrambling is syntactically optional. This is not exceptional since A'-movement as well as A-movement are optional to a certain extent, too.

\section{Scrambling - a predictable epiphenomenon of phrase structuring}

Scrambling is a system potential of particular phrase-structure configurations. The structural patterns we look at when we look at instances of scrambling are head-final phrases (see Corver and van Riemsdijk 1997; Haider and Rosengren 1998, 2003) or phrases with unspecified directionality of the head of the phrase. The existence of the latter type, the "third type" or "T3" (Haider 2010: 162; Haider 2013: 131, Haider 2015) tends to be overlooked because the Greenbergian types are viewed as an exhaustive set of types. T3 languages are usually misclassified as SVO languages with an exceptional property, viz. exceptionally "free" word order.

18 One more example:

(i) The rooms cannot have been done anything with since it was built. (www.tripadvisor.com) 
In Generative Grammar, a proper understanding of scrambling as the reflex of an independent system potential of certain phrase structures is inaccessible since scrambling is modelled as movement to higher spec-positions. ${ }^{19}$

Spec-positions are not type-specific. They ought to be available in any language, that is, in SVO languages just as well as in SOV languages, contrary to the facts. Uncontroversial SVO languages do not scramble. Alleged SVO languages with scrambling - upon closer scrutiny - turn out to be T3 languages that are misclassified as SVO (see the discussion of Slavic languages below).

The crucial syntactic question is this: What is the essential syntactic difference between a scrambling and non-scrambling phrase structure setting? The current explanation in Generative Grammar is: Scrambling languages provide the necessary functional spec positions and non-scrambling languages don't. Such an "explanation" is merely camouflaging the problem by a technical jargon. The question still remains why precisely SOV (and type III) languages would provide such structures, but unquestionable [S[VO]] languages would not. Moreover, the question usually focuses on too narrow a set of data. Scrambling is not a sentencelevel property; it is a phenomenon of the phrasal level. Since the VP is the base constituent of a clause, its phrase level properties can easily be mistaken for sentence level properties. ${ }^{20}$ German is a handy demonstration case since it is headfinal for VPs and APs, but head-initial for NPs and PPs. In addition, any verb can be converted into a noun. This guarantees minimal pair patterns such as in (9). VPs (9-a), (9-b) and $\mathrm{APs}^{21}$ show order variation, NPs (9-c), (9-d) and PPs don't.

19 If this assumption is seriously put to test, nobody can overlook (but only suppress the fact) that scrambled items do not have the syntactic properties of phrases in preverbal spec-positions. They remain transparent for extractions, which no phrase in a preverbal spec position does (Haider 2010: 155-157):

(i) Was ${ }_{\mathrm{i}}$ hat denn $\left[\text { damit }-_{\mathrm{i}} \text { zu beweisen }\right]_{\mathrm{CP}}$ der Schreiber dieser Zeilen schon vor what has PRT [with-it to prove] the writer (of) these lines already before Jahrzehnten versucht?

decades tried

20 The strict locality property of scrambling (as opposed to the non-local kind of fronting) is a trivial consequence of the phrase-internal nature of the phenomenon.

21 Since APs do not contain overt subjects or direct objects, scrambling is less observable than with VPs.

(i) eine $[\text { allen an Intelligenz überlegene }]_{\mathrm{AP}}$ Frau

a [(to)-all.DAT in intelligence superior] woman

(ii) eine $\left[\text { an Intelligen } z_{\mathrm{i}} \text { allen } \mathrm{e}_{\mathrm{i}} \text { überlegene }\right]_{\mathrm{AP}}$ Frau

a [in intelligence (to)-all.DAT superior] woman 
(9) a. [gesunden Menschen gefährliche Medikamente verabreichen $]_{\mathrm{VP}}$

base order healthy people.DAT dangerous drugs.ACC administer.INF

b. [gefährliche Medikamente gesunden Menschen verabreichen $]_{\mathrm{VP}}$ scrambled

c. das [Verabreichen gefährlicher Medikamente an gesunde Menschen $]_{\mathrm{NP}}$ the administer.N dangerous drugs.GeN to healthy people base 'the administering of dangerous drugs to healthy people'

d. $\quad{ }^{\star}$ das [Verabreichen an gesunde Menschen gefährlicher Medikamente $]_{\mathrm{NP}} \quad$ scrambled

e. *das Verabreichen über lange Zeit solcher Medikamente the administer.N for long time such drugs.GEN

In a head-final VP, the serialization is variable (9-a), (9-b), in the head-initial NP it is not (9-c), (9-d). The NP patterns are identical with the patterns of English NPs or VPs: The serialization is strict, and the nominal object is immediately adjacent to the head. No adjunct may intervene (9-e), no item may be scrambled. Generative discussions of scrambling remain silent on scrambling in non-clausal domains. The structure of noun phrases is incompatible with the structural expenditures envisaged on the clause-level, but nevertheless, head-final NPs admit scrambling. Urdu, for instance, is a strictly head-final language and its NP-internal arguments scramble (Raza and Tafseer 2011).

Once it is acknowledged that scrambling is a phrase-level phenomenon, it is much easier to understand and capture the clear-cut typological contrast between languages with and without scrambling. Scrambling patterns are a system potential that follows from the licensing conditions which hold between the head of a phrase and its phrase mates; see Haider (1992a), Haider (2013: 57-61); Haider (2015: §4). The central conditions are as follows:

(10) i. Phrase-internal projection lines are universally right-branching. ${ }^{22}$

ii. A dependent phrase is licensed directionally (= in the parametric canonical direction)

iii. The position of a dependent phrase $\mathrm{P}$ is structurally licensed by the phrasal head $\mathrm{h}={ }_{\text {Def. }}$ (a projection of) the phrase head $\mathrm{h}$ and $\mathrm{P}$ minimally and mutually c-command each other.

It is the minimal and mutual c-command condition (10)-iii that is directly causal for many of the OV/VO contrasts in phrase structuring. Mutual c-command is fulfilled in sister positions or in chains. Here, A and B meet the mutual c-command relation if A c-commands the base of the chain while the head of the chain c-commands A.

22 In the diction of "merging": external and internal merge is to the left. "Phrase-internal" does not include the positions of adjunctions to a phrase. 
This is the structural source of the VP-shell organization of complex head-initial phrases. ${ }^{23}$

Type-defining properties of [S[VO]] languages, such as the shell-structure, the absence of scrambling, the Left-Left Constraint (Haider 2019a), and the obligatory presence of a functional subject position in the [S[VO]] clause structure, with the concomitant syntactic properties of a subject in an obligatory spec position, follow directly from (10), as demonstrated in detail by Haider (2015).

Please note that it is the very same principle (viz. universality of merger to the left) and the very same licensing condition applied under parametrized directionality that covers the different outcomes. Let us focus on scrambling. Scrambling patterns are patterns with variable order of arguments in a phrase. In head-final phrases (11-a), the base position and the re-ordered position of a phrase are positions within the directionality domain of the head. In head-initial phrases (11-b), the re-ordered phrase would end up outside of the directionality domain of the head. The arrows in (11) signify the direction of licensing, which, in head-final phrases, is "to the left".

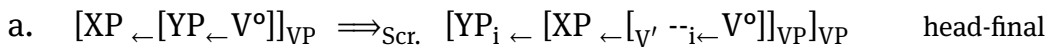
b. $\quad\left[\mathrm{XP}\left[\mathrm{V}^{\prime} \mathrm{V}^{\circ} \rightarrow \mathrm{YP}\right]\right]_{\mathrm{VP}} \Longrightarrow{ }_{\mathrm{Scr} .}{ }^{*}\left[\mathrm{YP}_{\mathrm{i}}\left[{ }_{\mathrm{VP}} \mathrm{XP}\left[\mathrm{V}_{\mathrm{V}^{\prime}} \rightarrow \mathrm{V}^{\circ} \rightarrow-_{\mathrm{i}}\right]\right]_{\mathrm{VP} \rightarrow}\right]_{\mathrm{VP}}$ head-initial

Scrambling does not transgress the licensing domain. Hence, strictly head-initial phrases are incompatible with scrambling to the left edge since it would leave the directionality domain of the head. As for scrambling within the directionality domain of a head, the minimality condition (10)-iii prevents the pattern (12-a) in English but permits (12-b) in German or Dutch.

$$
\begin{aligned}
& \text { a. } \quad[\text { send several mails to friends }] \\
& \text { b. } \quad \text { [einige Mails an Freunde schicken }] \Longrightarrow[\text { [an Freunde einige Mails schicken }]
\end{aligned}
$$

The scrambled pattern in (12-a), but not in (12-b), violates the minimal and mutual c-command condition (10)-iii. The scrambled item in (12-a) is an illicit intervener that blocks the minimal c-command relation between the licensing verbal head

23 (i) $\left[V_{V P} V^{o}{ }_{i}\left[X P\left[e_{V^{o}-i} Y P\right]\right]\right]$.

In a head-initial transitive VP (i), the verb needs to be instantiated twice, otherwise it could not directionally license XP. This is the immediate source of the V-chain ("VP-shell", "little v") in complex head-initial VPs. The verb c-commands XP and XP c-commands a link of the V-chain. Mutual-c-command also explains why subjects move to Spec-T in SVO languages: The subject is not directionally licensed by the verb since it precedes. The directional licenser is a pre-VP functional head. Mutual c-command is fulfilled if the subject raises to the spec position of the functional head. Here it c-commands the functional head which in turn c-commands the base position of the subject. 
and the licensee. Several mails in the scrambled variant of (12-a) is not minimally c-commanded by a licensing head. Another case of an illicit intervener would be a VP-internal adverbial. It also destroys the minimal c-command relation between the phrase-initial head and its argument.

In OV (13-b), any projection of the verb is a licit licenser, since any projecting node is a sister node with the required canonical directionality property. Hence the minimal and mutual c-command relation is guaranteed in any position within the phrase, preceding the head. In the VO setting, a scrambled variant of (12-a), as in (13-a), would be an instance of (13-c). Any intervener $\pi$, viz. a scrambled phrase or an adjunct, destroys the minimal c-command relation. This is the reason for the compactness property of head-initial phrases. No adjunct may intervene between the verbal head and its nominal arguments and no phrase can be scrambled to such a position in a head-initial phrase. In head-final phrases, this is not the case, neither empirically not theoretically (13-e).
a. $\quad . . .\left[\right.$ send $\rightarrow\left[{ }^{\star}\right.$ to friends $\left.\left.]\left[\text { several mails }\left[\text { send }_{\rightarrow}{ }^{--_{\mathrm{i}}}\right]_{\rightarrow}\right]_{\rightarrow}\right]\right]$
$\mathrm{VO}$
b. $\quad . . .\left[[\right.$ an Freunde $] \leftarrow\left[\right.$ einige Mails $\leftarrow_{\leftarrow}\left[-_{\mathrm{i}} \leftarrow\right.$ schicken $\left.\left.]\right]\right]$
OV
c. $\quad . . .\left[\right.$ send $\left.\rightarrow\left[[\pi]\left[\text { several mails }[\text { send } \rightarrow \text { to friends }]_{\rightarrow}\right]_{\rightarrow}\right]\right]$
$\mathrm{VO}$
d. ... send ( ${ }^{\star}$ today) some friends ( ${ }^{\star}$ hastily) several mails
$\mathrm{VO}$
e. ... an einige Freunden heute einige Mails hastig verschicken
OV
to some friends today several mails hastily send

In German, VPs are head-final, NPs are head-initial. Hence, scrambling is possible in VPs but not in NPs. VPs admit VP-internal adverb positions, but NPs don't [see (9-e)]. The latter property correlates with the former. Phrase-internal scrambling and phrase-internal adjuncts are excluded by the same principle, namely (10)-iii in head-initial phrases. This pattern has been wrongly generalized from English to other languages, such as Dutch. This unjustified transfer is the source of the idea of "Dutch scrambling”. NPs preceding VP-internal adjuncts are analysed as scrambled merely because in English adjuncts precede a VP and are banned from VP-internal positions. However, this is not a universal property. It is a particular property of head-initial phrases. Dutch does not scramble NPs in clear cases of scrambling, as in (14-c), or in double-object constructions such as (14-d), and hence it does not scramble across adverbials. The alternative serialization of adverbials merely reflects the availability of alternative slots for adverbials in headfinal phrases.

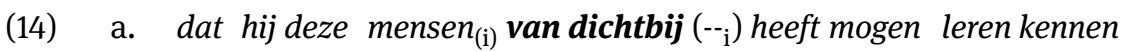
that he these people at close-range has wanted get to-know 
b. omdat hij mensen $(\mathrm{i})$ graag $\left(-_{-}\right)$helpt bij een gezonde leefstijl because he people gladly helps with a healthy lifestyle

c. *Stoort de buren $_{\mathrm{i}}$ het geluid $--_{\mathrm{i}}$ ? annoys the neighbours the noise

d. ${ }^{\star}$ Toen hebben de autoriteiten het kind $d_{\mathrm{i}}$ de moeder $-_{-\mathrm{i}}$ teruggegeven. then have the authorities the child the mother back-given

In Dutch, scrambling is limited to arguments that are morphologically uniquely identifiable. This is the case with PP-objects (15), as acknowledged by Dutch standard grammars (e. g. Geerts et al. 1984: 989-990).

a. Toen hebben de autoriteiten het kind aan de moeder teruggegeven. then have the authorities the child to the mother back-given

b. Toen hebben de autoriteiten aan de moeder ${ }_{\mathrm{i}}$ het kind $-_{-} \mathrm{i}$ then have the authorities to the mother the child teruggegeve.

back-given

Structures as exemplified by (15-b) identify Dutch as a scrambling language, which is what is predicted for a language with a head-final VP. The English counterparts with a scrambled PP would be ungrammatical, as predicted. The lack of case morphology of NPs in Dutch is likely to contribute to the lack of NP scrambling. ${ }^{24}$ However, the absence of morphological case distinctions for NPs is compatible with scrambling, as Bulgarian attests. Slavic languages are notorious for their word order variations, and Bulgarian shares most of them, in the absence of morphological case-marking of NPs. Icelandic on the other hand, as an [S[VO]] language, forbids scrambling, despite its rich case morphology (Dehé 2004: 94).

Slavic languages are generally filed as SVO languages. The following section will argue that this categorization is in need of revision. Even if the order Subject $>$ Verb $>$ Object is a frequent order in Slavic languages, these languages do

24 Although pronouns are distinctively case-marked, they are fronted only rarely. Here are Dutch excerpts from Volkskrant (i); N. Neuhaus, Diepe wonden \& Sneeuwwitje moet sterven (ii); Daagblad van het Norden (iii):

(i) omdat hem $_{i}$ de vuurkracht $-_{-}$ontbeert because him.oвJ the firepower.suBj lacks

(ii) omdat hem ${ }_{\mathrm{i}}$ niets anders $-_{\mathrm{i}}$ te binnen wilde schieten because him nothing else to mind would come

(iii) omdat zich $\boldsymbol{h}_{\mathrm{i}}$ een tweede getuige -- ${ }_{\mathrm{i}}$ heeft gemeld because himself a second witness reported has 
not share the structural architecture of [S[VO]] languages. They are languages of a type of its own. They are languages in which the directionality of the lexical heads of a phrase, and in particular of the VP, is unspecified. So, they are able to license phrases in either direction. This brings about a huge potential for word order variation since it combines with scrambling.

To sum up, the variable serialization of arguments (viz. scrambling) is the outcome of a structuring potential of head-final phrases (and of phrases with "variable" head-positioning, as will be shown in the following section). Any reordered phrase (by adjunction or "internal merge") remains within the directionality domain of the head. The very same licensing conditions applied to head-initial phrases rule out reordering arguments within head-initial phrase or across the phrase-initial head. The differences reduce to a single factor, namely the directionality value for the standard licensing directionality of a lexical head.

\section{Scrambling in Slavic languages}

The correlation between scrambling and head-positioning seems to be at odds with the word order freedom of Slavic languages, if it were correct that these languages are [S[VO]] languages. They are not.

"Anything goes" is - in fewest words - the appropriate characterization of the wealth of word order variations in Slavic declarative clauses: "Apart from the location of clitics there are virtually no syntactic constraints on the ordering of phrases in main declarative clauses. Thus in each of the Slavic languages all twenty-four possible combinations of a subject, direct object, indirect object and verb occur as grammatical declarative orders.” (Siewierska and Uhliřová 2010: 109)

Since the time when Ross (1967) framed the later discussion by coining the term "scrambling”, Slavic clauses have been identified as apparent hotspots of reordering a basically English-like clause structure. This approach is missing an essential generalization, however. If scrambling were such an easily available grammatical option for SVO languages, why would there be so many strictly headinitial SVO languages with rigid word order and other recurrent properties that are all absent in Slavic languages? Either Slavic languages are highly exceptional SVO languages or the rigid SVO languages are exceptionally rigid.

This apparent impasse can be resolved so that neither group is exceptional. The English-like languages are languages with uniformly head-initial phrases, plus a VP-external, obligatory, structural subject position, or, in other words, languages with an [S[VO]] clause structure. The Slavic languages are not exceptional either. They are well-behaved members of a different phrase structure type, 
namely the "third type" (T3), that is, languages without specified directionality values for the (verbal) head of a phrase. Such heads can license in either direction.

An immediate consequence is a VP in which the verbal head may appear in any structurally available position (16); see Szucsich and Haider (2015) and Haider and Szucsich (2019). One of the available and frequently employed serializations is subject > verb > object. Since this pattern seems to be preferred (for whatever reason), it is more frequent than other equally grammatical, that is, well-formed patterns. However, frequency is not a syntactic property. It is a fact about language use. Grammars characterize the well-formedness of patterns, irrespective of their frequency. The less frequent ones are as "grammatical" as the more frequent ones. In (16), the T3-compatible projections of a VP are listed in such a way that the partial overlap with serialization patterns of other types is recognizable.

(16) Alternative head-positioning in T3-type VPs, with XP and YP as objects
a. $\left[\mathrm{XP}\left[\mathrm{YP} \mathrm{V}^{\circ}\right]\right]_{\mathrm{VP}}$
(= OV-like)
b. $\left[\mathrm{V}_{\mathrm{i}}{ }^{\circ}\left[\mathrm{XP}\left[-_{\mathrm{i}} \mathrm{YP}\right]\right]\right]_{\mathrm{VP}}$
(= VO-like)
c. $\left[\mathrm{XP}\left[\mathrm{V}^{\circ} \mathrm{YP}\right]\right]_{\mathrm{VP}}$
(= T3-only)

The Polish examples in (17) - see Leszkowicz (2015: 121) - illustrate the patterns in (16). In all these patterns, the relative order of subject and objects is the same; it is the verb position that changes. Logically, in a series of three items, there are four possible positions for the fourth one: at the end, at the beginning, and two in-between. This is true for the verb in a finite Slavic main clause with three arguments. A single theoretical property - unspecified head-directionality - covers the four empirically attested patterns. In addition, the arguments may scramble, that is, change their relative order, just like in OV. V-positioning plus the re-positioning of arguments within the directionality domain of the verb, as it is familiar from head-final structures, cover the other twenty variants. In sum, the word order variations in T3 languages, such as the Slavic languages, are a combination of the scrambling options familiar from OV languages with the V-positioning options of T3 languages.
a. (̇e) Marek
Ewie kwiaty
dat.
SOV-like that Marek.Nom Eve.DAT flowers.Acc gave
b. (ze) Marek dat $_{\rightarrow}$ Ewie kwiaty.
SVO-like
c. (̇e) dat $\rightarrow$ Marek Ewie kwiaty.
VSO-like
d. (ze) Marek Ewie dat $_{\rightarrow}$ kwiaty.
T3-only

In an [S[VO]]-based analysis, (17-b) has been assumed to be closest to the base structure. In (17-a), the two objects are deemed to be scrambled (to functional spec positions). In (17-d), only the indirect object would count as scrambled. (17-c) can- 
not be derived from (17-b) by scrambling. So, V-fronting has to be added to the analysis kit. Unfortunately for the proponents, independent evidence for these derivations is missing. The preverbal objects in (17-a) and (17-d) have not, and cannot, be shown to have the predictable properties of arguments in spec positions. Counterevidence tends to be downgraded.

Here is a core prediction that goes back to the intensive research on conditions on extraction domains. In SVO languages, any phrase above the VP level is inaccessible for filler-gap structures that terminate inside such phrases. In other words, a phrase in such a positions blocks any extraction. This is neither true for the preverbal objects in (17-a), (17-d) nor for the subject in Slavic languages. (18) is a well-known construction that is absent in an unquestionable SVO language, namely “left-branch” extraction (see Grosu 1973):
a. Jaki $i_{\mathrm{i}} \quad J a r e k\left[--_{\mathrm{i}}\right.$ samochód] kupit swojej żonie? which Jarek car bought his wife

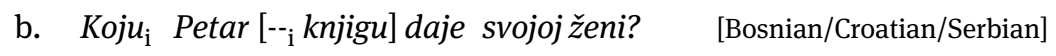 which Petar book gives his wife
c. Kakuju $u_{\mathrm{i}}$ Ivan [-- mašinu] kupil svoej žene?
[Russian] which Ivan car] boughthis wife
d. Japonskuju $u_{\mathrm{i}}$ Ivan $\left[-_{\mathrm{i}}\right.$ mašinu] kupil svoejžene. Japanese Ivan car bought his wife

In each example in (18), the gap-containing phrase is preverbal. Nevertheless, each construction is acceptable, given an appropriate context for the information structure effect of the particular word order with a preverbal object. The respective grammars of these languages do not rule out such a construction, the reason being that the noun phrase that contains the gap is in the directionality domain of the verb, and the attribute phrase is in the directionality domain of the nominal head. Hence, the syntactic conditions for filler-gap dependencies are fulfilled. Note that this is a trivial consequence of heads without a specified licensing directionality. The license in both directions.

In English neither the preverbal nominal phrase itself nor its attribute would be within the directionality domain of a phrase-internal head. In German, it is the attribute that is not in the directionality domain of the head-noun. This is the syntactic reason of the restriction known as "left-branch constraint" (Ross 1967: 123). Left branches of VPs are easily fronted in German since these VPs are head final.

Here are two additional facts out of the set of deducible predictions that correctly describe Slavic grammars once they are filed as grammars of T3 rather than SVO languages (Haider and Szucsich 2019; Szucsich and Haider 2015). The first 
fact is the obligatoriness of a structural subject position in [S[VO]] languages. The second fact is a fact about adjuncts that immediately precede a head-initial phrase, viz. the Left-Left constraint (LLC).

The mandatory VP-external, structural subject position in [S[VO]] languages is a particularly unerring indicator of an [S[VO]] status of clause structure. In the absence of a subject argument, this position must be lexicalized by a dummy. In OV languages, there is no VP-external structural position for a subject attestable, available, or required, since any argument of the verb is within the directionality domain of the verbal head (Haider 2019b). The ultimate test case for [S[VO]] is the mandatory presence of an expletive subject in an otherwise subjectless sentence. The passive of an intransitive verb is the locus classicus. Passive deprives (intransitive) verbs of their would-be subject argument. In the case of intransitives, the resulting construction becomes subjectless. An expletive lexicalizes the obligatory structural subject position in the [S[VO]] clause structure. This is the expletive subject known from SVO languages such as the Scandinavian languages (19-a) or French (19-b), (19-c). English is the only Germanic language in which intransitive verbs cannot be passivized, since there is no available expletive because neither it nor there can serve as expletives, see Haider (2019b). ${ }^{25}$
a. og derfor blevet der danset
[Danish] and therefore is EXPL danced (Vikner 1995: 209)
b. Il a beaucoupété fumé danscette salle it has much been smoked in this room (Gaatone 1998: 124) [French]
c. Il a été dormidansce lit [French] it has been slept in this bed (Rivière 1981: 42)

Romance languages are particularly instructive in this respect. Intransitive verbs cannot be passivized in any Romance null-subject (standard) language by standard passivisation, that is, participle plus auxiliary. The grammatical reason behind this invariable property is simple. The counterpart of the pronominal subject expletive of French would be null in the null-subject languages. Italian (20-a)
25 (i) ${ }^{\star} I t /{ }^{\star}$ There has been applauded/coughed/feasted/laughed/... - dass applaudiert/ gehustet/gefeiert/gelacht wurde.

There is associated with a postverbal subject argument. Cross-linguistically, it would be a candidate for a subject expletive (see for instance French il), too, but not in the Anglo-Saxon diachrony (see Dutch er, instead of het). 
and Spanish (20-b) are representative in this respect of any Romance null-subject standard language. Intransitive verbs cannot be passivized because there is no expletive available. These languages are demonstrations of the non-existence of "null expletives". A null-subject language with a pronominal expletive would "realize" the expletive as a "null expletive". If such an oxymoronic concept ${ }^{26}$ existed, it would predictably have to be employed in null-subject languages, but it is not.

a. *In questo letto è stato dormito bene

[Italian] in this bed has been slept well (Lamiroy 2000:142)

b. *Aquí fue trabajado duro here was worked hard (Cabredo Hofherr 2008)

[Spanish]

In a nutshell, what these data show is as follows. If, in a given language, intransitive verbs can be passivized in the absence of a lexical subject expletive, the language is definitely not an [S[VO]] language. This is true for null-subject languages as well as for languages without this property. In [S[VO]] languages, the VP-external, structural subject position must not be radically empty. If there is no filler available, this mandatory position must be plugged with an expletive. A silent expletive would be irrecoverable. Hence null-subject languages cannot employ pronominal expletives. ${ }^{27}$ The expletive would fall victim to the null subject property.

Grewendorf (1990: 210) contested the above claim, that had first been posited in Haider (1987), by referring to the fact that Russian clauses with passivized intransitive verbs (21-a), (21-b) do not feature an expletive subject. This is so, indeed, but it does not demonstrate at all that Russian is a testimony for null expletives.

26 The concept is oxymoronic since a "null expletive" aka "empty expletive" would be something empty used for filling a position that must not remain empty. The idea originated as an auxiliary hypothesis against evidence from non-SVO languages (Dutch, German), which falsifies the alleged EPP-universal (= Every clause has a subject):

(i) dass heute nicht gearbeitet wurde

[German] that today not worked was

(ii) Dat vandaag niet werd gewonnen lag niet alleen aan het veld. that today not was won was-due not solely to the field

[Dutch]

27 An adverbial expletive would not fall prey to the null subject property, and there exist regional varieties indeed, with an expletive in an intransitive passive, such as Venetian: Z'è stà parlà de ti. 'There has been spoken about you'. My gratitude goes to Cecilia Poletto (p. c.), who is native in this language, for certifying it. 
What Russian and Bulgarian (21-c), (21-d) are testimonies for is the fact that Slavic languages are not [S[VO]] and therefore are not obliged to lexicalise an allegedly universal, obligatory subject position of an [S[VO]] clause structure (21-a), (21-b). In $\mathrm{T} 3$ languages, in SOV and in $\mathrm{VSO}^{28}$ languages, too, there is no (structural position for a) VP external functional subject since pre- and postverbal argument positions are within the directionality domain of the (ambidirectional) verbal head. Hence there is neither room nor need for an expletive subject.
a. V komnate bylo nakureno
[Russian] in room was smoked
b. Ob ètom bylo napisano $v$ gazete about this was written in newspaper
c. V stajat e vlizano
[Bulgarian] in room is entered (Desclés and Guentchéva 1996: 56)
d. Po trevata est xodeno on grass.DEF is walk.IMPF.PPT

Let us turn now to the LLC. This is a constraint on left-adjoined adjuncts to leftheaded (= head-initial) phrases, that is, adjuncts off-side of the directionality domain of the head of the phrase (Haider 2019a). In a language like English or French, with head-initial VP and NPs, LLC restricts prenominal attributes as well as preverbal adverbial phrases.

(22) a. [a much easier (*than I thought)] task.

b. The new boss will [much more often ( ${ }^{\star}$ than you would like)] call you into his office.

c. Lausanne a $\left[\left[\right.\right.$ plus souvent ( ${ }^{\star}$ que Berne $\left.)\right]$ perdu $] .{ }^{29}$ [French] Lausanne has more often than Bern lost

d. une $\left[\left[\text { fière ( }{ }^{\star} \text { d'elle-même) }\right]_{\mathrm{AP}}\right.$ nation] vs. une $[$ nation $[$ fière
a proud of itself
nation
(d'elle-même) $]_{\mathrm{AP}}$ ]

28 McCloskey (1996: 261) emphasized that in a VSO language such a Irish, subjectless sentences do not contain an expletive subject:

(i) nuair a bhí tráite síos uaidh when Comp was ebbed down from-it 'when the tide had ebbed down from it' 
German and Dutch are head-initial with NPs but head-final with VPs. So the LLC is at work only in NPs (23-b), (23-d), but not in head-final VPs (23-a), (23-c). If Slavic languages were [S[VO]] languages, the LLC is predicted to constrain prenominal attributes as well as preverbal adverbial phrases, just like in English and any other SVO language.

(23) a. Sie hat das Problem genau so schnell (wie ihr Konkurrent) gelöst she has the problem exactly as fast as her competitor solved

[German]

b. eine [fast so geniale (*wie Newtons) Lösung

an almost as ingenious as Newton.GEN solution

c. De ziekte heeft zich [veel sneller (dan werd verwacht)] the disease has itself much faster than was expected verspreid.

[Dutch] spread

d. een [veel sneller ( ${ }^{\star}$ dan een fietser)] paard a much faster than a cyclist horse

If VPs are T3 phrase-structures in Slavic languages, and NPs, too, LLC-effects are predicted to be absent in any of these phrases, and this is the case indeed, as the examples in (24) and (25) illustrate. Extraposition of the comparative PP is an alternative and may be stylistically preferred, whence the slight degradation in (24-b), but the given order is grammatical and acceptable.

a. V prošlom godu [gorazdo bol'še čem Igor] vyigrala tol'ko Maša in previous year much more than Igor won only Mary

[Russian]

'Last year, only Mary has much more won than Igor.'

b. ?W zeszłym roku [dużo więcej niż Jarek] pracowała tylko Roza in last year much more than Jarek worked only Roza

[Polish]

(25)
a. [verni-jat (na žena si)] măž
faithful-DEF to wife his.REFL husband

[Bulgarian]

29 The only licit option for plus souvent que ... in this position is parenthetic. A parenthesis is not integrated into the phrase structure and hence it is not subject to the LLC:

(i) et doit, plus souvent que moi, souffrir de la faim

and must, more often than me, suffer from the hunger 
b. [vernyj (svoej žene)] muž

[Russian]

faithful his wife.DAT husband

c. [wierny (swojej żonie)] mąz

[Polish]

faithful his wife.DAT husband

Let us summarize this section: The properties under discussion, namely scrambling, variable V-positioning, lack of subject expletives in subjectless clauses, and the absence of LLC effects are independent properties. Their uniting bond is the T3 nature of the phrasal architecture in Slavic languages. For those who insist that Slavic languages are [S[VO]] languages with exceptional properties, all these properties are completely unexpected and independent "exceptions", and there are more "exceptions" of this kind (see Haider and Szucsich 2019), which follow straightforwardly from the T3 analysis.

\section{A sketch of a null theory of scrambling}

For a syntactical characterization of scrambling, it is sufficient to identify the conditions that provide room for reordering the base order of items within phrases. The resulting potential of order variation is occupied by other modules that partition the set of order variants in terms of order preferences of their own. Here is once more a non-exhaustive, merely illustrative list of the resulting effects that call for explanation and coverage.

- Scrambling separates the domains of given and new information.

- Scrambling clears the clause final area of unfocused items.

- Scrambling provides contiguity for idiom formation with subject plus verb.

- Scrambling extends the binding domain of quantifiers for variable-binding.

- Scrambling extends the scoping domain of quantifiers.

- Scrambling is found in head-final VPs, APs, and NPs.

- Scrambling is absent in head-initial phrase structure settings.

- $\quad$... and so on.

Phenomenologically, scrambling is word order variation. Grammatically, scrambling is a structural property, namely the availability of alternative structural positions for the arguments of the head of a phrase within the directionality domain of the head. It is this structural property that accounts for the scrambling potential of phrases cross-linguistically. Let us start with the simple case of a verb whose licensing directionality is "to the left", as indicated by the subscripted arrows in (26). 

a. $\left[\mathrm{A}_{1} \leftarrow \mathrm{V}^{\circ}\right]_{\mathrm{VP}}$
b. $\left[A_{1} \leftarrow\left[A_{2} \leftarrow V^{\circ}\right]\right.$
c. $\left[A_{1 \leftarrow}\left[A_{2} \leftarrow\left[A_{3} \leftarrow V^{\circ}\right]\right.\right.$
d. $\quad\left[A_{2-i} \leftarrow\left[A_{1} \leftarrow-^{-} i \leftarrow V^{0}\right]\right.$

Arguments are serialized according to their ranking in the lexical argument structure and according to the right-branching constraint [viz. merger "to the left"; (10)-i]. The result is - depending on the number of arguments to be projected one of the three VP-structures in (26-a)-(26-c). Next, let us compare (26-d), viz. the scrambled variant of (26-b), with (26-c). The two phrases are structured isomorphically. The difference lies only in the number of arguments. In (26-c) the structure accommodates three arguments in three argument positions. In (26-d), however, the structure contains the very same three positions, but only two arguments, since one is not in its base position anymore, that is, not in the position in which it is projected according to the ranking of arguments in the lexicalargument structure of the verbal head. This position is empty and counts as a gap position whose filler is higher up in the structure, in an another argument position. This configuration is rendered possible because a head-final head is able to license any position merged to the left of it or one of its projections because the directionality of licensing is identical with the universal directionality of merger, that is, "to the left".

The situation is entirely different for head-initial projections, despite the fact that the same rules and principles are at work. The essential difference is the $d i-$ rectionality mismatch between the parametric direction of licensing (10)-ii and the universal direction of merging (10)-i. The head of a head-initial phrase ${ }^{30}$ licenses "to the right", but merger is to the left. A minimal compatible structure is (27-a). Once there is more than one argument, it is projected outside of the directionality domain of the head, as in (27-b). If $A_{x}$ is the subject, it gets licensed by a functional head that selects the structure (27-b) as a VP. Since licensing requires minimal and mutual c-command, $A_{x}$ is raised to the spec position of the functional head.

$$
\begin{array}{ll}
\text { a. } & {\left[\mathrm{V}^{\mathrm{o}} \rightarrow \mathrm{A}\right]} \\
\text { b. } & {\left[\mathrm{A}_{\mathrm{x}}\left[\mathrm{V}^{\mathrm{o}} \rightarrow \mathrm{A}_{\mathrm{y}}\right]\right]}
\end{array}
$$

How is the VP structured if there is more than one object to be accommodated? Let's assume, $A_{x}$ and $A_{y}$ are the two objects of a double object verb. Then $A_{x}$ is

30 In the VP-shell, each position on the head-chain is a licenser (“ $\rightarrow$ ”):

(i) $\quad\left[\operatorname{explain}_{\mathrm{i}} \rightarrow\left[\right.\right.$ readers $\left[\mathrm{e}_{\mathrm{i}} \rightarrow\right.$ the problem $\left.]\right]$. 
not directionally licensed in its position in (27-b) by the verbal head since the head, and therefore any projection of the head, licenses only "to the right". The grammatical solution is this: The verb is re-instantiated in a higher position (28-a). This is the grammatical causality of the "shell"-structure ${ }^{31}$ of complex head-initial phrases. There is only a single head item, but it has to be instantiated in two positions. So, the result is a filler-gap dependency, aka head-chain. What tends to be constantly overlooked by grammarians who stare only at VPs like (28-a) is the fact that complex head-initial NPs (28-b) are structured in the same way (Haider 1992a,b).

$$
\begin{array}{ll}
\text { a. } & {\left[\mathrm{V}^{\circ}{ }_{\mathrm{i}}\left[\mathrm{A}_{\mathrm{x}}\left[--_{\mathrm{i}} \rightarrow \mathrm{A}_{\mathrm{y}}\right]\right]\right]} \\
\text { b. } & {\left[\mathrm{N}^{\mathrm{o}}{ }_{\mathrm{i}}\left[\mathrm{A}_{\mathrm{x}}\left[-\mathrm{-}_{\mathrm{i}} \rightarrow \mathrm{A}_{\mathrm{y}}\right]\right]\right]}
\end{array}
$$

Structures such as (28-a) and (28-b), do not provide any room for scrambling. If one of the two arguments were placed in the phrase initial position, it would be outside of the directionality domain of the head. If on the other hand, $A_{y}$ were scrambled across $A_{x}$, the minimal c-command relation between the head and $A_{x}$ (necessitated by the general licensing constraint) would be disrupted [see (10)-iii]. In other words, the order in (28-a) and (28-b) is the only structurally available order for the objects $A_{x}$ and $A_{y} \cdot{ }^{32}$ As a consequence, head-initial phrases - VPs as well as NPs - are no domains of scrambling since the resulting structures are not well-formed VPs or NPs. As a consequence, serialization is invariant. This is a property of phrase structuring.

Let us turn now to head-final and T3-phrases. Such phrases provide ample room for variation. (29) lists the six possible serialization patterns for three phrases in a head-final VP. The first one (29-a) is the base order. The other five options are structures with a serialization that is not the serialization of the base order of arguments as determined by the lexical argument structure of the verbal head. However, any position in this structure is a position within the directionality domain of the head and hence a possible A-position. The choice of one of these structures depends on the interaction with other modules, such as IS or Binding.

$$
\begin{array}{ll}
\text { a. } & {\left[\mathrm { A } _ { 1 } \leftarrow \left[\mathrm{A}_{2} \leftarrow\left[\mathrm{A}_{\left.\left.\left.3 \leftarrow \mathrm{V}^{\circ}\right]\right]\right]}\right] \text { b. }\left[\mathrm{A}_{1}\left[\mathrm{~A}_{3-\mathrm{i}}\left[\mathrm{A}_{2}\left[-_{-\mathrm{i}} \mathrm{V}^{\circ}\right]\right]\right]\right]\right.\right.}
\end{array}
$$

SOV base order SOV scrambled

\footnotetext{
31 Note that the lower position is just the base position of the re-instantiated head. There is no need of inventing a "little v" category. It follows immediately from the system, and, it follows only for head-initial phrases. The fruitless search for "little v" in OV languages can be ended. There simply is no "little v" in a head-final VP.

32 The verb is re-instantiated in a higher position only for licensing the immediately discharged, positionally unlicensed argument and not for an already licensed argument.
} 
c. $\left[\mathrm{A}_{3-\mathrm{i}}\left[\mathrm{A}_{1}\left[\mathrm{~A}_{2}\left[-_{-\mathrm{i}} \mathrm{V}^{\circ}\right]\right]\right]\right]$

SOV scrambled

d. $\left[A_{2-j}\left[A_{1}\left[--j\left[A_{3-i} V^{\circ}\right]\right]\right]\right]$

SOV scrambled

e. $\left[A_{2-\mathrm{j}}\left[A_{3-\mathrm{i}}\left[\mathrm{A}_{1}\left[-_{-\mathrm{j}}\left[-_{-\mathrm{i}} \mathrm{V}^{0}\right]\right]\right]\right]\right]$

SOV scrambled

f. $\left[A_{3-\mathrm{j}}\left[\mathrm{A}_{2-\mathrm{i}}\left[\mathrm{A}_{1}\left[-_{-\mathrm{j}}\left[-_{\mathrm{i}} \mathrm{V}^{\circ}\right]\right]\right]\right]\right.$

SOV scrambled

Here are some illustrations of (29). (30-a) is the base order (29-a). (30-b) is an instance of (29-e). (30-c) is based on (29-d), with the lowest V'-constituent fronted to the clause-initial position.

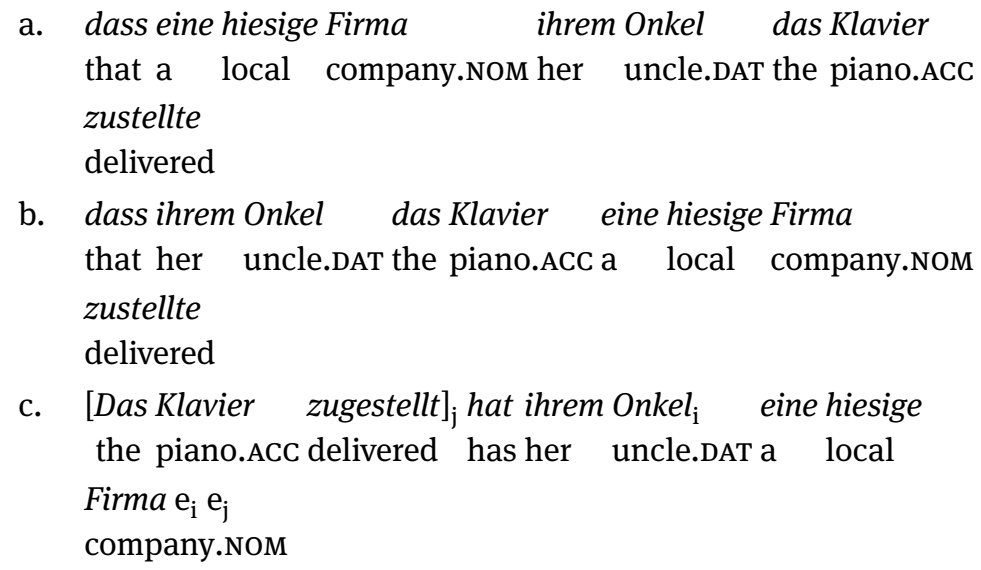

a. dass eine hiesige Firma ihrem Onkel das Klavier that a local company.NOM her uncle.DAT the piano.ACC zustellte

delivered

b. dass ihrem Onkel das Klavier eine hiesige Firma that her uncle.DAT the piano.ACC a local company.NOM zustellte

delivered

c. [Das Klavier zugestellt $]_{\mathrm{j}}$ hat ihrem Onkel $\mathrm{i}_{\mathrm{i}}$ eine hiesige the piano.ACC delivered has her uncle.DAT a local

Firma $\mathrm{e}_{\mathrm{i}} \mathrm{e}_{\mathrm{j}}$ company.NOM

IS typically partitions a structure into (contiguous) sections, such as "given" vs. "focused". (30-c) would be a felicitous answer to a question like "Who moved the piano to her uncle's flat?". The topic part, that is, the information already contained in the question is presented first, in the fronted V-projection. Background information precedes the focal part, that is, the subject as the question-answer focus. (29-f) is the structure that meets these requirements and hence it is selected by a speaker.

Analogous considerations apply to items that are subject to binding conditions. If the binder is a lower-ranked argument, then its domain can be enlarged by fronting. In (31), the quantified direct object binds the pronominal variable, that is, the possessive pronoun of the subject. The suitable structure is the structure with a scrambled direct object.

a. wenn jeden ${ }^{\mathrm{i}}$ Menschen sein ${ }^{\mathrm{i}}$ Engel als Wächter

if each human-being.ACc his angel.NOM as custodian begleiten würde

accompany would

(Zeitschrift für die historische Theologie, Vol.12: 108) 
Let us turn now to T3-phrases. Since the licensing domain of the head of a T3-phrase is not restricted directionally, it licenses ambidirectionally (32). As a consequence, T3-phrases have the full variation (= scrambling) potential of head-final phrases, since any position is within the domain of the head. A second variation potential comes from variable head-positioning. In (32), the alternative head-positions of the verb are indicated by brackets. Taken together, these two dimensions of structural variation account for the famous word order freedom of phrases and clause in Slavic and other T3 languages.

$$
\left[\left(\mathrm{V}_{\rightarrow}^{\circ}\right) \mathrm{A}_{1}\left(\leftarrow \mathrm{V}_{\rightarrow}^{\circ}\right) \mathrm{A}_{3}\left(\leftarrow \mathrm{V}^{\circ} \rightarrow\right) \mathrm{A}_{2}\left(\leftarrow \mathrm{V}^{\circ}\right)\right]_{\mathrm{VP}}
$$

As in the head-final setting, the alternative verb positioning as well as the availability of scrambling positions for arguments is utilized and partitioned by other modules of grammar, notably by IS. Slavic word order has preferably been described in terms of information structure categories (theme, rheme, communicative units) because these are the phenomenological and easily detectable repercussions of serialization variations in Slavic languages (see Firbas 1992).

\section{Concluding remark}

The cross-linguistic incidence of "scrambling" is a by-product of phrase structuring. The parametric directional licensing relation that associates the head of a phrase with its phrase mates brings about a potential for variation in headfinal and T3-phrases. This syntactic potential is occupied and partitioned by components of grammar superimposed to syntax, such as information structuring, binding, scoping, or prosody. Properties that seem to immediately correlate with scrambling are not syntactic triggers but resultant properties of superimposed systems that utilize the variation space provided by certain phrase structures. The apparently incoherent set of alleged triggers is but the incoherent aggregate of properties of subsystems that utilize the variation space.

Acknowledgements: The author gratefully acknowledges that the paper has benefitted greatly from comments, suggestions and objections of two anonymous reviewers. 


\section{References}

Adger, David. 2018. The autonomy of syntax. In Norbert Hornstein, Howard Lasnik, Pritty Patel-Grosz \& Charles Yang (eds.), Syntactic Structures after 60 years: The impact of the Chomskyan revolution in linguistics, 153-176. Berlin \& Boston: Mouton de Gruyter.

Bolinger, Dwight. 1975. On the passive in English. In Adam Makkai \& Valerie Becker Makkai (eds.), The first LACUS Forum 1974, 57-77. Columbia, SC: Hornbeam Press.

Breitbarth, Anne \& Henk van Riemsdijk. 2013. The role of triggers in linguistic theory: Some introductory remarks. In Anne Breitbarth \& Henk van Riemsdijk (eds.), Triggers, 1-13. Berlin \& Boston: Mouton de Gruyter.

Cabredo Hofherr, Patricia. 2008. The subjects of impersonal passives in German and Spanish. Ms., Université Paris 8. http://archive.sfl.cnrs.fr/sites/sfl/IMG/pdf/cabredo05pass.pdf.

Corver, Norbert \& Henk van Riemsdijk. 1997. The position of the head and the domain of scrambling. In Bohumil Palek (ed.), Proceedings of LP'96: Typology: Prototypes, item orderings and universals, 59-90. Prague: Charles University Press.

Dehé, Nicole. 2004. On the order of objects in Icelandic double object constructions. UCL Working Papers in Linguistics 16. 85-108.

Desclés Jean-Pierre \& Zlatka Guentchéva. 1996. Passivization in Bulgarian: A formal approach. University of Trondheim Working Papers in Linguistics 28. 55-74.

Engdahl, Elisabet \& Anu Laanemets. 2015. Prepositional passives in Danish, Norwegian and Swedish: A corpus study. Nordic Journal of Linguistics 38(3). 285-337.

Erdmann, Oskar. 1886. Grundzüge der deutschen Syntax nach ihrer geschichtlichen Entwicklung, Vol. 1. Stuttgart: Verlag der J. G. Cotta'schen Buchhandlung. [Reprint Hildesheim: Georg Olms Verlag, 1985].

Fanselow, Gisbert. 2003. Free constituent order: A minimalist interface account. Folia Linguistica 37(1-2). 191-232.

Firbas, Jan. 1992. Functional sentence perspective in written and spoken communication. Cambridge: Cambridge University Press.

Gaatone, David. 1998. Le passif en français. Paris \& Bruxelles: Duculot.

Geerts, Guido, Walter Haeseryn, Jaap de Rooij \& Maarten C. van den Toorn. 1984. Algemene Nederlandse Spraakkunst. Groningen: Wolters-Noordhoff.

Grewendorf, Günther. 1990. Small pro in German. In Günther Grewendorf \& Wolfgang Sternefeld (eds.), Scrambling and barriers, 295-315. Amsterdam: Benjamins.

Grosu, Alex. 1973. On the left branch condition. Linguistic Inquiry 5. 308-319.

Haider, Hubert. 1987. Expletives pro - eine Phantomkategorie. In Wolfgang U. Dressler, Corrado Grassi, Rosita Rindler-Schjerve \& Martin Stegu (eds.), Parallela III, 237-247. Tübingen: Narr.

Haider, Hubert. 1992a. Branching and discharge. Working Papers of the SFB 340, No. 23. Stuttgart: Universität Stuttgart. [Reprinted in Peter Coopmans, Martin Everaert \& Jane Grimshaw (eds.), Lexical specification and insertion, 135-164. Amsterdam: Benjamins, 2000].

Haider, Hubert. 1992b. Die Struktur der Nominalphrase - Lexikalische und funktionale Strukturen. In Ludger Hoffmann (ed.), Deutsche Syntax. Ansichten und Aussichten, 304-333. Berlin \& New York: de Gruyter.

Haider, Hubert. 1993. Deutsche Syntax, generativ. Tübingen: Narr.

Haider, Hubert. 2010. The syntax of German. Cambridge: Cambridge University Press. 
Haider, Hubert. 2013. Symmetry breaking in syntax. Cambridge: Cambridge University Press. Haider, Hubert. 2015. Head directionality - in syntax and morphology. In Antonio Fábregas, Jaume Mateu \& Mike Putnam (eds.), Contemporary linguistic parameters, 73-97. London: Bloomsbury Academic.

Haider, Hubert. 2019a. The Left-Left Constraint - a structural constraint on adjuncts. In Ulrike Freywald \& Horst Simon (eds.), Headedness and/or Grammatical Anarchy? Berlin: Language Science Press (to appear).

Haider, Hubert. 2019b. On absent, expletive, and non-referential subjects. In Peter Herbeck, Bernhard Pöll \& Anne C. Wolfsgruber (eds.), Semantic and syntactic aspects of impersonality, 11-46. Hamburg: Buske.

Haider, Hubert \& Inger Rosengren. 1998. Scrambling. Sprache und Pragmatik 49. 1-104. Haider, Hubert \& Inger Rosengren. 2003. Scrambling - non-triggered chain formation in OV languages. Journal of Germanic Linguistics 15(3). 203-267.

Haider, Hubert \& Luka Szucsich. 2019. Slavic languages - "SVO" languages without SVO qualities? To appear in Theoretical Linguistics. https://www.academia.edu/35967992/ Slavic_languages_SVO_languages_without_SVO_qualities.

Hinterhölzl, Roland. 2004. Scrambling, optionality and non-lexical triggers. In Anne Breitbarth \& Henk van Riemsdijk (eds.), Triggers, 173-204. Berlin \& Boston: Mouton de Gruyter.

Hinterhölzl, Roland. 2013. (Dis)Harmonic word order and phase-based restrictions on phrasing and spell-out. In Theresa Biberauer \& Michelle Sheehan (eds.), Theoretical approaches to disharmonic word order, 162-189. Oxford: Oxford University Press.

Lamiroy, Béatrice. 2000. Sur certains rapports entre le passif pronominal et les datifs non-lexicaux. In Hans Peter Lund (ed.), Le passif, 135-154. Copenhagen: Tusculanum Press.

Lenerz, Jürgen. 1977. Zur Abfolge nominaler Satzglieder im Deutschen. Tübingen: Narr. Leszkowicz, Joanna 2015. Scrambling im Polnischen als A-bar-Bewegung. In Elena Dieser (ed.), Linguistische Beiträge zur Slavistik: XX. JungslavistInnen-Treffen in Würzburg, 22.-24. September 2011, 117-133. München: Otto Sagner.

Lødrup, Helge. 1991. The Norwegian pseudo-passive in lexical theory. Working Papers in Scandinavian Syntax 47. 118-129.

McCloskey, James. 1996. Subjects and subject positions in Irish. In Robert D. Borsley \& Ian G. Roberts (eds.), The syntax of the Celtic languages: A comparative perspective, 241-283. Cambridge: Cambridge University Press.

Meinunger, André. 2019. Wie und wo Ambiguität Ungrammatikalität vortäuscht. In Jessica Brown, Andreas Schmidt \& Marta Wierzba (eds.), Of trees and birds: A Festschrift for Gisbert Fanselow, 171-184. Potsdam: Universitätsverlag.

Molnárfi, László. 2004. On scrambling as defocusing in German and West Germanic. In Anne Breitbarth \& Henk van Riemsdijk (eds.), Triggers, 331-386. Berlin \& New York: Mouton de Gruyter.

O'Grady, William. 1998. The syntax of idioms. Natural Language and Linguistic Theory 16(2). 279-312.

Raza, Ghulam \& Ahmed Tafseer. 2011. Argument scrambling within Urdu NPs. In Miriam Butt \& Tracy Holloway King (eds.), Proceedings of the LFG11 Conference, 461-481. Stanford, CA: CSLI Publications.

Rivière, Nicole. 1981. La construction impersonnelle en français contemporain (Documents de Linguistique Quantitative, no. 41). St. Sulpice-de-Favière: Éditions Jean-Favard. 
Rogers Timothy T. \& James L. McClelland. 2014. Parallel distributed processing at 25: Further explorations in the microstructure of cognition. Cognitive Science 38. 1024-1077.

Ross, John R. 1967. Constraints on variables in syntax. Cambridge, MA: MIT dissertation. [Published as Infinite syntax! Norwood, NJ: Ablex Publishing, 1987].

Siewierska, Anna \& Ludmila Uhliřová. 2010. An overview of word order in Slavic languages. In Anna Siewierska (ed.), Constituent order in the languages of Europe, 105-150. Berlin \& New York: de Gruyter Mouton.

Simon, Herbert A. 1962. The architecture of complexity. Proceedings of the American Philosophical Society 106(6). 467-482.

Struckmeier, Volker. 2017. Against information structure heads: a relational analysis of German scrambling. Glossa: A Journal of General Linguistics 2(1). 1-29.

Struckmeier, Volker. 2016. Scrambling in German is driven by prosody and semantics. In Kyeong-min Kim, Pocholo Umbal, Trevor Block et al. (eds.), WCCFL 33: Proceedings of the 33rd West Coast Conference on Formal Linguistics, 381-389. Somerville, MA: Cascadilla Press.

Szucsich, Luka \& Hubert Haider. 2015. Freie Wortstellung in slavischen Sprachen und die VO/OV-Unterscheidung. In Elena Dieser (ed.), Linguistische Beiträge zur Slavistik: XX. JungslavistInnen-Treffen in Würzburg, 22.-24. September 2011, 94-124. München: Otto Sagner.

Taraldsen, Tarald K. 1979. Remarks on some central problems of Norwegian syntax. Nordic Journal of Linguistics 2. 23-54.

Truswell, Robert. 2009. Preposition-stranding, passivization, and extraction from adjuncts in Germanic. In Jeroen van Craenenbroeck \& Johan Rooryck (eds.), Linguistic Variation Yearbook 8, 131-177. Amsterdam: Benjamins.

Vikner, Sten. 1995. Verb movement and expletive subjects in the Germanic Languages. Oxford: Oxford University Press. 